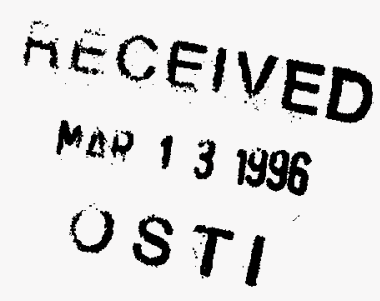

\title{
Effect of Passage Number on Cellular Response to DNA-damaging Agents: Cell Survival and Gene Expression
}

\author{
Chin-Mei Chang-Liu and Gayle E. Woloschak* \\ Center for Mechanistic Biology and Biotechnology \\ Argonne National Laboratory \\ 9700 South Cass Avenue \\ Argonne, Illinois 60439-4833 USA \\ Telephone (708) 252-3312 \\ Fax (708) 252-3387
}

\section{DISCLAIMER}

This report was prepared as an account of work sponsored by an agency of the United States Government. Neither the United States Government nor any agency thereof, nor any of their employees, makes any warranty, express or implied, or assumes any legal liability or responsibility for the accuracy, completeness, or usefulness of any information, apparatus, product, or process disclosed, or represents that its use would not infringe privately owned rights. Reference herein to any specific commercial product, process, or service by trade name, trademark, manufacturer, or otherwise does not necessarily constitute or imply its endorsement, recommendation, or favoring by the United States Government or any agency thereof. The views and opinions of authors expressed herein do not necessarily state or reflect those of the United States Government or any agency thereof.

"Author to whom correspondence should be addressed The submitted manuscript has been authored
by a contractor of the U.S. Government
under contract No. W-31-109-ENG-38.
Accordingly, the U. S. Government retains a
nonexclusive, rovalty-free license to publish
or reproduce the published form of this
contribution, or allow others to do so, for
U.S. Government purnoses. 


\section{DISCLAMMER}

Portions of this document may be illegible in electronic image products. Images are produced from the best available original document. 
This work was supported by the U.S. Department of Energy, Office of Health and Environmental Research, under contract No. W-31-109-ENG-38.

Abbreviated Title: Responses to DNA-damaging Agents

Key Words: DNA-damaging agents; cell passage numbers; gene expression; radiation sensitivity; radiationinduced genes 


\section{ABSTRACT}

The effect of different passage numbers on plating efficiency, doubling time, cell growth, and radiation sensitivity was assessed in Syrian hamster embryo (SHE) cells. Changes in gene expression after UV or $\boldsymbol{\gamma}$-ray irradiation at different passage numbers were also examined. The SHE cells were maintained in culture medium for up to 64 passages. Cells were exposed to ${ }^{60} \mathrm{Co} \gamma$ rays or $254-\mathrm{nm}$ UV radiation. Differential display of CDNAs and Northern blots were used for the study of gene expression. With increasing passage number, SHE cells demonstrated decreased doubling time, increased plating efficiency, and a decreased yield in the number of cells per plate. Between passages 41 and 48 a "crisis" period was evident during which time cell growth in high serum (20\%) was no longer optimal, and serum concentrations were reduced (to $10 \%$ ) to maintain cell growth. Sensitivity to ionizing radiation was no different between early- and intermediate-passage cells. However, after UV exposure at low passages (passage 3), confluent cells were more sensitive to the killing effects of UV than were log-phase cells. At intermediate passages (passages 43,48 ), confluent cells were slightly more radioresistant than were log-phase cells. By passage 64, however, both confluent and log-phase cells showed similar patterns of UV sensitivity. Expression of $\gamma$-actin, PCNA, and p53 transcripts did not change following UV exposure. p53 mRNA was induced following $\gamma$-ray exposure of the intermediate lpassage 45) epithelial cells. Differential display, however, revealed 
changes in expression of several transcripts following exposure to ionizing and ultraviolet radiations. The observed differences in radiation sensitivity associated with increasing passage number may be influenced by radiation-induced gene expression. We are conducting experiments to identify these genes. 


\section{INTRODUCTION}

The functional relationship between radiation-induced cellular responses (such as apoptosis, DNA repair, etc.) and radiationmediated changes in gene expression has been explored by a number of different laboratories in the past several years [1-15]. Genes induced after radiation exposure include those encoding cytokines [1-3], cell cycle arrest proteins [4,5], viruses [6-8], cell signal transducing agents [9,10], cytoskeletal elements [11,12], apoptosis-associated proteins [13], and a variety of unknown genes $[4,14,15]$. However, the precise role that this specific gene induction plays in the functional consequences of radiation exposure is still unknown.

In the experiments reported here, we set out first to explore the relationship between cell passage number and generation doubling time, plating efficiency, UV and radiosensitivity, and cell growth. Second, we designed experiments to examine relative gene expression as a consequence of radiation exposure and cell passage number. We chose the $\mathrm{SHE}^{3}$ cells for these studies because of the large body of literature examining radiation effects on these normal cells $[1,9,11-13,16]$, our previous experience with these cells, and the well-known growth characteristics of these cells $[1,16]$. 
The experiments reported here establish the following as a consequence of increasing cell passage number: decreased cell doubling time, decreased saturation (cell yield/plate), and increased plating efficiency. In addition, a reversion in the UV sensitivity of confluent and log-phase cells was apparent. At early passage (passage 3) the confluent cells are more-sensitive to the killing effects of UV than log phase cells; at intermediate passage the log phase became more sensitive than the confluent cells and at late passage the exponentially growing cells are equally as sensitive as the confluent cells. These changes are accompanied with changes in control, $\gamma$-ray, and UV-induced gene expression. Ionizing radiation sensitivities did not change with passage number, but changes in gene expression were also evident in control and $\gamma$-ray exposed cells.

\section{MATERIALS AND METHODS}

\section{Ce11s and Culture Conditions}

In all experiments, we examined the modulation of gene expression after exposure to UV and ionizing radiations in SHE fibroblasts; primary cultures were normal diploid cells that could be neoplastically transformed by low doses of ionizing radiation $[1,16]$. 
All cell cultures were established in Dulbecco's modified Eagle's medium containing $10 \%$ or $20 \%$ fetal calf serum (as indicated in the text), $2 \mathrm{mM}$ glutamine, penicillin (100 units/ml), and streptomycin (100 units/ml), called DH-104. Cells were grown to confluence; $48 \mathrm{~h}$ before irradiation, they were placed in medium containing $1.0 \%$ fetal calf serum to maintain the cells in plateau phase. Studies of preirradiated early passage SHE cells grown under this protocol showed them to be a mixed population of fibroblasts, with $>90-95 \%$ of the cells in the $G_{0}-G_{1}$ phase of the cell cycle. Cells for the present experiments were from passages 3-64, as indicated throughout the text. Cells from the initial culture are called SHE-H3 cells, with the passage number indicated by a $\mathrm{P}$ after $\mathrm{H} 3$. We have cultured SHE cells from early passages [2-6] for previous experiments $[1,9,11-13,16]$, and these cells appeared similar in morphology to the others at early passages.

\section{Radiation Treatments}

For $\gamma$-ray exposures, cells were plated in $100-\mathrm{mm}$ Petri plates containing $10 \mathrm{ml}$ medium and irradiated with ${ }^{60} \mathrm{Co} \gamma$ rays at the indicated doses and dose rates. All irradiations were performed with the cells kept at $37^{\circ} \mathrm{C}$. Control cells were taken to the radiation chamber but not exposed to radiation. Plates of cells were then incubated at $37^{\circ} \mathrm{C}$ for 1 or $3 \mathrm{~h}$ after irradiation but before harvest of the RNA. 
Exposures to $254-\mathrm{nm}$ UV radiation were carried out at room temperature by using a GE60TS 30-W germicidal lamp (General Electric) that was contained in a sterile hood. The irradiations were at a distance of $55.6 \mathrm{~cm}$ from the source. The dose rate for all exposures to UVC radiation was $2.5 \mathrm{~J} \cdot \mathrm{m}^{-2} \cdot \mathrm{s}^{-1}$. The media were removed from the 100-mm plates, and the plates were washed once with cold phosphate-buffered saline and irradiated without covers. The media were replaced immediately after irradiation.

\section{Parameters of Cell Growth}

Determination of cell doubling times, plating efficiencies, and the numbers of cells per plate was carried out as described previously $[1,17]$. Viable cell counts (based on $>1000$ cells) were determined by trypan blue dye exclusion. Cell survival experiments were determined by cell survival in 8-day colony assays [17-19] .

\section{Purification of RNA and Northern Blots}

RNA was prepared by isolation in 3 M guanidine isothiocynate, extraction with phenol, and precipitation from $3 \mathrm{M}$ sodium acetate, pH 6.0 [14,16,17]. Purified RNA was obtained by digestion with DNase I $\left(37^{\circ} \mathrm{C}\right.$ for $\left.1 \mathrm{~h}\right)$. PolyA+ RNA was purified and Northern blots were performed as described previously [1,9]. Total and PolyA+ RNA were used as indicated throughout the paper. 
CDNA Probes

CDNA clones were generously provided by the following: p53 by American Type Culture Collection (Bethesda, MD), $\gamma$-actin by Dr. L. Kedes (Stanford University, Palo Alto, CA), PCNA by Dr. R. Bravo (Bristol Myers), and ODC by Dr. P. Coffino (University of California, San Francisco, CA).

\section{Differential Display}

The following primers were used for all experiments reported here: one $3^{\prime}$ primer: $(T)_{11} \mathrm{CA}: T T T T T T T T T T T C A ;$ one $5^{\prime}$ primer: R1 : TCCTGTGACC.

RNA template was mixed with $20 \mathrm{pM}$ of $(\mathrm{T})_{12} \mathrm{XY}$ primer in a total volume of $19 \mu \mathrm{l}$ of $1 \times$ reaction buffer $(50 \mathrm{mM}$ Tris $\mathrm{HCl}$ [pH 8.3], 75 $\mathrm{mM} \mathrm{KCl}$ and $\left.3 \mathrm{mM} \mathrm{MgCl}_{2}\right), 20 \mu \mathrm{M} \mathrm{dNTP}, 10 \mathrm{mM} \mathrm{DTT}$ and incubated $5 \mathrm{~min}$ at $65^{\circ} \mathrm{C}$ and then $10 \mathrm{~min}$ at $37^{\circ} \mathrm{C}$. M-MLV reverse transcriptase (GIBCO-BRL, Bethesda, MD) was added (200 units per sample) and mix incubated for $50 \mathrm{~min}$ at $37^{\circ} \mathrm{C}$. Enzyme inactivation incubation was $5 \mathrm{~min}$ at $95^{\circ} \mathrm{C}[20-23]$.

For a single reaction, $4 \mu \mathrm{l}$ of labeled primer mix was added to $8 \mathrm{pM}$ of cold primer and $1 \mu l$ of reverse transcription $\operatorname{mix}$ in $1 \times$ PCR buffer $(10 \mathrm{mM}$ Tris $\mathrm{HCl}[\mathrm{pH} 8.3], 50 \mathrm{mM} \mathrm{KCl}, 1.5 \mathrm{mM} \mathrm{MgCl}$, and $0.001 \%$ gelatin) and 2 or $200 \mu \mathrm{M}$ dNTP in the presence of $0.5 \mu$ AmpliTaq enzyme (Perkin Elmer). The total volume of the reaction was $10 \mu l$. One drop of mineral oil was added, and PCR was 
performed in a Perkin Elmer Cetus Thermal Cycler. PCR parameters were $94{ }^{\circ} \mathrm{C}$ for $30 \mathrm{~s}, 40{ }^{\circ} \mathrm{C}$ for $2 \mathrm{~min}, 72{ }^{\circ} \mathrm{C}$ for $30 \mathrm{~s}$ with 40 cycles, followed by 5 -min elongation at $72{ }^{\circ} \mathrm{C}$.

For a single PCR, 10 pM of primer was labeled. The reaction mixture with a final volume of $5 \mu 1$ included $10 \mathrm{pM}$ of oligonucleotide, $6 \mathrm{pM}$ of $\left[\gamma^{-32} \mathrm{P}\right] \mathrm{ATP}(3000 \mathrm{Ci} / \mathrm{mmol} ; \mathrm{New}$ England Nuclear) in $1 \times$ kinase buffer $\left(50 \mathrm{mM}\right.$ Tris $\mathrm{Cl}[\mathrm{pH} 8], 10 \mathrm{mM} \mathrm{MgCl}_{2}$, $5 \mathrm{mM}$ DTT, $0.1 \mathrm{mM}$ spermidine, $0.1 \mathrm{mM}$ EDTA) with 2 units of $\mathrm{T} 4$ polynucleotide kinase (Promega, Madison, WI). Reaction mixture was incubated $45 \mathrm{~min}$ at $37^{\circ} \mathrm{C}$, followed by 5 -min enzyme inactivation at $95^{\circ} \mathrm{C}$.

After PCR, samples were mixed 5:2 with formamide and dye "stop" solution (United States Biochemical), the mixture was heated at $80^{\circ} \mathrm{C}$ for $2 \mathrm{~min}$ and cooled to $0{ }^{\circ} \mathrm{C}$. Four-microliter aliquots were run on standard sequencing $(0.45$-mm-thick) denaturing gels ( $6 \%$ Hydro Link Long-Ranger, $42 \mathrm{~g}$ urea per $100 \mathrm{ml}$ gel, 1 × Tris borate, $0.05 \%$ ammonium persulfate, $50 \mu \mathrm{l}$ TEMED per $100 \mathrm{ml}$ gel) on $50 \mathrm{~W}$ for $3.5 \mathrm{~h}$. 


\section{RESULTS}

\section{Effects of Passage Number on Cell Growth}

SHE-H3 fibroblasts were harvested directly from pooled hamster embryos derived from the second pregnancy of five different mothers; cells were cultured for up to 68 passages and monitored for the various parameters of cell growth at specific passages. Figure 1 documents results from the entire experiment by depicting changes in plating efficiency, cell doubling time, and the number of confluent cells per plate as a function of cell culture passage number. These experiments established a decrease in doubling time, a decrease in the saturation density (or number of confluent cells per plate), and an increase in plating efficiency with increasing passage number. A "crisis" in the culture was apparent beginning at passage 37 ; at that time it was necessary to shift the cultures from 20\% fetal calf serum (which was used for the initial primary cultures) to $10 \%$ fetal calf serum to allow for cell survival. This crisis period, which was evident until passage 49, was characterized by dramatic daily and weekly changes in plating efficiencies and cell growth parameters.

From these cultures, specific passages were selected for further analysis. The history of these cells and other growth characteristics are depicted in Table 1 . This table documents the growth conditions and growth parameters (including half-life, 
plating efficiency, etc.) for each of the passages. SHE-H3 cells that retained fibroblast characteristics were examined at passages $1,3,45,48$, and 64. An epidermal subline (H3CE) was obtained at passage 40 and analyzed at passage 45 to allow for a determination of possible cell subtype differences. A more detailed analysis is depicted in Fig. 2 in which these selected passages of. fibroblasts (passages 3,48, and 64) were compared for plating efficiency and doubling time. In addition, one culture showing morphological features of the epidermal (rather than fibroblastic) cells was also compared at passage 43. Doubling time and plating efficiency for that cell were similar to those observed for similar-passage (passage 48) SHE-H3 cells.

\section{Effects of Passage Number on Radiosensitivity}

The next series of experiments were performed to determine the effects of cell passage number on sensitivity to ionizing and UV radiations. Table 2 presents the results from experiments in which the survival rate was examined after exposure of cells to 96 cGy of ${ }^{60} \mathrm{Co} \gamma$ rays. There was no difference in the survival rate of early(passage 1) or medium-passage (passage 45) SHE-H3 fibroblasts after $\boldsymbol{\gamma}$-ray exposure. The epidermal cells (SHE-H3CE) did show increased radiosensitivity, which may be attributed to cell type differences.

Studies of the effects of cell passage number on UV sensitivity are depicted in Table 3 which compares cultures of SHEH3 cells from passages 3,48 , and 64. These results showed a 
change in the $D_{0}$ value with passage number. Early- and latepassage cells showed similar $D_{0}$ values, but the intermediatepassage (passage 48) cells had markedly lower $D_{0}$ values than either early or late passage cells. This was not related to cell type since the epidermal type SHE cells (SHE-H3CE) from passage 43 also expressed low $D_{0}$ values.

Comparisons of survival curves for each of these cells from selected passage numbers after UV exposure of the cultures either in log phase or when confluent are evident in Fig. 3. In Figure 3A, it is apparent that passage 3 cells had increased UV-resistance when in log phase. Figure $3 \mathrm{~B}$ demonstrates that in intermediatepassage (passage 48) cells, the confluent cultures are more resistant than the log-phase cultures over most of the survival curve. However, in late-passage (passage 64) cultures, the logphase and confluent cultures were similar with respect to survival curve. The intermediate-passage (passage 43) epidermal cells (Fig. 3D) showed a more dramatic resistance of confluent cells even than the intermediate-passage fibroblasts. In addition, the confluent cells appear to have a resistant tail, suggesting the presence of a resistant cell subpopulation in the cultures or the possible shielding of a subset of cells in the Petri plate from UV radiation (perhaps those around the perimeter). 


\section{Effects of Passage Number on Gene Expression}

Initially, we set out to examine the expression of several known genes as a function of passage number and radiation exposure. Untreated and irradiated (96 CGy) confluent fibroblasts and epidermal SHE cells from various passages (1, 40, 45) were harvested $1 \mathrm{~h}$ post-radiation exposure. RNA was prepared and Northern blots were performed. Figure 4 presents results from several such experiments. $\quad \gamma$-actin mRNA is expressed similarly regardless of passage, cell type (H3 fibroblasts vs. H3CE epidermal cells), RNA preparation (total or Poly $A+$ ) or $\gamma$-ray exposure. PCNA mRNA expression was enhanced in later passages regardless of radiation exposure or cell type. mRNA specific for p53, however, was detectable only in $\gamma$-ray exposed H3CE epidermal cells. This $\gamma$ ray induction of p53 mRNA was not detected in any other passages or in the intermediate passage $\mathrm{H} 3$ fibroblasts. These transcripts (PCNA and p53) could not be adequately detected in total RNA preparations (data not shown). mRNA for ornithine decarboxylase (ODC) was poorly detected in all of the preparations and quantitation was not possible (data not shown).

Effects of UV exposure $\left(5-75 \mathrm{Jm}^{-2}\right)$ administered at a dose-rate of $2.5 \mathrm{Jm}^{-2} / \mathrm{sec}$ ) on SHE cells from the same passages described above (for $\gamma$-ray exposures) similarly revealed that changes in $\gamma$-actin and PCNA RNA were passage-related and not affected by UV exposure. p53 was not induced following UV exposure of cells from any 
passage, including the $\mathrm{H} 3 \mathrm{CE}$ epithelial cells which showed p53 mRNA induction following $\gamma$-ray exposure above (data not shown). This suggests that p53 induction in epidermal cells may be specific for $\gamma$-rays

Overall, these experiments suggested little effect of cell passage on radiation-mediated gene expression. We therefore performed cDNA differential display to examine gene expression in a less directed manner. Figure 5 depicts a differential display gel in which expression of arbitrary genes (as determined by selected arbitrary primers) as described in Materials and Methods was studied before and after exposure of early-and intermediatepassage SHE-H3 cells to UV, $\boldsymbol{\gamma}$ rays, or both. These experiments revealed (a) few if any detectable differences in expression of genes when comparing untreated early- and intermediate-passage cells, (b) several common differences when comparing untreated with irradiated ( $\gamma$ ray or UV) cells from both low and intermediate passages, (c) several differences between UV-induced and $\gamma-r^{-}$ induced genes, and (d) several genes induced to a greater extent in the low-passage cells than in the intermediate-passage cells or vice versa. These experiments suggest that radiation-induced gene expression may contribute to the observed differences in radiosensitivity associated with changing passage number. Work is underway to identify these genes. 


\section{DISCUSSION}

This work explored the effect of cell passage number on doubling time, plating efficiency, cell growth, and sensitivity to radiation. The results of these experiments indicated decreased doubling time and cell yield per plate but increasing plating efficiency with increasing passage number (Table 4). In addition, while sensitivity to ionizing radiation was not affected, UV sensitivity, especially with regard to cell cycle effects, was markedly dependent on passage number. In early-passage cells, confluent cells were more sensitive than log-phase cells; a tendency in the reverse was apparent with intermediate-passage cells. By late passage (passage 64), log-phase and confluent cultures demonstrated similar patterns of sensitivity to $U V$. In addition, changes in gene expression were found to accompany these alterations in radiosensitivity. This is probably not surprising in light of the fact that with each passage there is a selection for faster growing, better plating cells. Many investigators [17-19] note that cells progress toward transformation with increasing passage number. The fact that doubling time decreases la feature characteristic of many transformed relative to nontransformed cell lines) is not surprising. This may be causally related to the cell cycle differences in UV radiosensitivity found associated with increasing passage number. 
The appearance of a "crisis" period in long-term cultures is well documented in the literature [20-22]. It has been hypothesized that this is related to the achievement of growth factor independence in the culture, another step associated with increasing transformation. The fact that this crisis is associated with lower serum requirements confirms a possible growth factor influence. This is further supported by the finding that fewer cells per plate and decreased cell doubling time also occur with increasing passage number. Autocrine growth factors may replace exogenous factors during the crisis period.

Studies of changes in expression of known genes with radiation exposure and cell passage number revealed few differences. $\gamma$-actin mRNA was unaffected by exposure to $\gamma$-rays, or irradiation, a result which is consistent with previous work from our group [11,12]. PCNA expression also did not change following exposure to UV or $\gamma$ rays, although the early passage (passage 1] fibroblasts expressed lower levels than the intermediate passage cells. This is not surprising in light of the fact that PCNA is a cell cycle-specific transcript [23] and that later passage cells have an increased doubling time relative to the early passage cells (Fig. 2). p53mRNA was undetected in all untreated fibroblast cell cultures. Epidermal type $\mathrm{H} 3 \mathrm{CE}$ cells isolated at passage 45 expressed p53 mRNA only following exposure to $\gamma$ rays (but not following exposure to UV). This is interesting in light of the fact that most studies have reported $p 53$ induction at the protein but not at the mRNA 
level $[26,27]$. It is not clear whether this $\gamma$-ray induction of p53 in the $\mathrm{H} 3 \mathrm{CE}$ cells is due to their epidermal characteristics or whether the cells are partially transformed (based on growth characteristics, plating efficiency, etc. described throughout this manuscript) or perhaps have acquired a p53 mutation/alteration. These experiments do suggest, however, that $\gamma$-ray induction of p53 can occur. It.s induction is not related to cell passage alone since intermediate passage $\mathrm{H} 3$ cells do not induce p53 following $\gamma$-ray exposure alone. $\mathrm{p} 53$ induction was not observed following UV exposure, suggesting that p53 induction in these cells is $\gamma$-rayspecific.

We observed no changes in radiation-mediated gene expression during the first hour following radiation exposure as a function of passage alone, using specific gene probes. Therefore, we used differential display to determine whether any radiation-induced genes are modulated as a function of cell passage. The differential display technique has been used to identify genes induced by different exposures [28-31]. In these experiments, however, we used differential display as an indicator of gene expression changes associated with passage number and radiation exposure. The results of our experiments indicated few if any ubvious differences in expression of genes when comparing earlyand intermediate-passage cells. This is interesting in light of the noted dissimilarities of these cells (Table 4) and suggests that only a few genes are mediating changes in plating efficiency, 
cell growth pattern, and doubling time. We observed several common genes when comparing low- and intermediate-passage cells for radiation-induced genes. In previous work with SHE cell cultures, our group identified well over 20 genes inducible after exposure to $\gamma$ rays $[1,6,9,11-13,16]$, and other groups $[2-5,7,8,10,14,15]$ have similarly documented a large number of UV- and $\gamma$-ray-inducible genes. It is not surprising then to find genes commonly induced in low- and intermediate-passage cells after radiation exposure. What is probably of most interest and functional significance is that a few genes were induced to a greater extent in low-passage cells than in the intermediate-passage cells and, conversely, that a few genes were induced to a greater extent in intermediate-passage cells thar in low-passage cells. These genes may play an important role in determining the radiosensitive and radioresistance patterns of cells at different passages. Experiments are underway to identify these genes. 


\section{ACKNOWLEDGMENTS}

The authors wish to thank Kay Bexson for excellent secretarial assistance, Gordon Holmblad for his assistance in irradiations, and Drs. Meyrick Peak and Jeffrey Schwartz for review of the manuscript before submission. 


\section{REFERENCES}

1. Woloschak GE, Liu C-M, Jones PS, Jones CA. Modulation of gene expression in Syrian hamster embryo cells following ionizing radiation. Cancer Res 50:339-344, 1990 .

2. Hallahan DE, Spriggs DR, Beckett MA, Kufe DW, Weichselbaum RR. Increased tumor necrosis factor $\alpha$ mRNA after cellular exposure to ionizing radiation. Proc Natl Acad SCi USA 86:10104-10107, 1989 .

3. Angel P: Imagawa M, Chiu R, Stein B, Imbra RJ, Rahmsdorf JH, Jonat C, Herrlich P, Karin M. Phorbol ester-inducible genes contain a common cis element recognized by a TPA-modulated trans-acting facior. Cell 49:729-739, 1987.

4. Fornace Jr AJ, Nebert DW, Hollander MC, Luethy JD, Papathanasiou M, Fargnoli J, Holbrook NJ. Mammalian genes coordinately regulated by growth arrest signals and DNA damaging agents. Mol Cell Biol 9:4196-4203, 1989 .

5. Papathanasiou MA, Kerr NCK, Robbins JH, MCBride OW, Alamo Jr I, Barrett SF, Hickson ID, Fornace Jr AJ. Induction by ionizing radiation of the gadd $^{45}$ gene in cultured human cells: lack of mediation by protein kinase C. Mol Cell Biol $11: 1009-1016,1991$ 
6. Panozzo J, Bertoncini D, Miller D, Libertin CR, Woloschak GE. Modulation of expression of virus-like elements following exposure of mice to high- and low-LET radiations. Carcinogenesis $12: 801-804,1991$.

7. Ronai ZA, Weinstein IB. Identification of ultravioletinducible proteins that bind to a TGACAACA sequence in the Polyoma Virus Regulatory Region. Cancer Res 50:5374-5381, 1990.

8. Zmudzka BZ, Beer JZ. Activation of human immunodeficiency virus by ultraviolet radiation. Photochem Photobiol $52: 1153-1162,1990$.

9. Woloschak GE, Liu C-M, Shearin-Jones P. Regulation of protein kinase C by ionizing radiation. Cancer Res 50:3963-3967, 1990 .

10. Karin $M$, Herrlich P. Cis- and trans-acting genetic elements responsible for induction of specific genes by tumor promoters, serum factors, and stress. In: Colburn NH (ed), Genes and Signal Transduction in Multistage Carcinogenesis, Marcel Dekker, New York, 1989, pp. 415-440.

11. Woloschak GE, Shearin-Jones P, Chang-Liu C-M. Effects of ionizing radiation on expression of genes encoding 
cytoskeletal elements: kinetics and dose effects. Mol Carcinog $3: 374-378,1990$.

12. Woloschak GE, Chang-Liu C-M. Expression of cytoskeletal elements in proliferating cells following radiation exposure. Int J Radiat Biol 59:1173-1183, 1991.

13. Woloschak GE, Chang-Liu C-M, Panozzo J, Libertin CR. Low doses of neutrons induce changes in gene expression. Radiat Res $138:$ S56-S59, 1994 .

14. Boothman DA, Bouvard I, Hughes EN. Identification and characterization of $\mathrm{x}$-ray-induced proteins in human cells. Cancer Res 49:2871-2878, 1989 .

15. Weichselbaum RR, Hallahan DE, Sukhatme VP, Kufe DW. Transcriptional induction of early response genes by X-rays. In: Chapman JD, Dewey WC, Whitmore GF (eds), Radiation Research: A Twentieth Century Perspective, Vol 1. Academic Press, San Diego, 1991.

16. Woloschak GE, Chang-Liu C-M. Differential modulation of specific gene expression following high- and low-LET radiations. Radiat Res 124:183-187, 1990. 
17. Todaro GJ, Green H. Quantitative studies of the growth of mouse embryo cells in culture and their development into established lines. J Cell Biol 17:299-313, 1963.

18. Brouty-Boyé D, Tucker RW, Folkman J. Transformed and neoplastic phenotype: reversibility during culture by cell density and cell shape. Int J Cancer 26:501-507, 1980.

19. Quintanilla M, Brown $K$, Ramsden $M$, Balmain A. Carcinogen specific mutation and amplification of Ha-ras during mouse skin carcinogenesis. Nature 322:78-79, 1986.

20. Hayflick L, Moorhead PS. The serial cultivation of human diploid cell strains. Exp Cell Res 25:585-621, 1961.

21. Pontén J. Westermark B. Cell generation and aging of nontransformed glial cells from adult humans. In: Fedorof $\mathrm{S}$, Hertz L (eds), Advances in Cellular Neurobiology, Academic Press, New York, 1980, pp. 209-227.

22. Hay RJ, Strehler BL. The limited growth span of cell strains isolated from the chick embryo. Exp Gerontol 2:123, 1967.

23. Jaskulski D, DeReil JK, Mercer WE, Calabretta B, Baserga R. Inhibition of cellular proliferation by antisense nucleotides to PCNA cyclin. Science 240:1544-1546, 1988. 
24. Jaskulski D, Gatti C, Travali S, Calabretta B, Baserga R. Regulation of the proliferating cell nuclear antigen cyclin and thymidine kinase mRNA levels by growth factors. J Biol Chem 263:10175-10179, 1988 .

25. Zuber ME, Tan M, Ryoji M. Involvement of proliferating cell nuclear antigen (PCNA) in DNA replication in living cells. Molec Cell Biol 9:57-66, 1989.

26. Kastan MB, Onyekwere O, Sidransky D, Vogelstein B, Craig RW. Participation of p53 protein in the cellular response to DNA damage. Cancer Res 51:6304-6311, 1991.

27. Kuerbitz SJ, Plunkett BS, Walsh WV, Kastan MB. Wild-type p53 is a cell cycle checkpoint determinant following irradiation. Próc Natl Acad Sci USA 89:7491-7495, 1992.

28. Bauer D, Müller H, Reich J, Riedel H, Ahrenkiel V, warthoe P, Strauss M. Identification of diffcrentially expressed mRNA species by an improved display technique (DDRT-PCR). Nucl Acids Res 21:4272-4280, 1993 .

29. Liang $P$, Pardee $A B$. Differential display of eukaryotic messenger RNA by means of the polymerase chain reaction. Science 257:969-971, 1992 . 
30. Liang P, Averboukh L, Pardee AB. Distribution and cloning of eukaryotic mRNAs by means of differential display: refinements and optimization. Nucl Acids Res 21:3269-3275 1993 .

31. Liang P, Averboukh L, Keyomarsi K, Sager R, Pardee AB. Differential display and cloning of messenger RNAs from human breast cancer versus mammary epithelial cells. Cancer Res $52: 6966-6968,1992$. 
Table 1. Cell history ${ }^{a}$

\begin{tabular}{|c|c|c|c|c|c|c|}
\hline $\begin{array}{l}\text { Cell line/ } \\
\text { Passage No. }\end{array}$ & $\begin{array}{l}\text { No of } \\
\text { initial } \\
\text { inoculated } \\
\text { cells/ } \\
\text { plate }\end{array}$ & $\begin{array}{l}\text { No. of } \\
\text { cells } \\
\text { harvested/ } \\
\text { plate }\end{array}$ & $\begin{array}{l}\text { Growth } \\
\text { period } \\
\text { (days) }\end{array}$ & $\begin{array}{l}\text { Harvested } \\
\text { cells/In- } \\
\text { oculated } \\
\text { cells }\end{array}$ & $\begin{array}{l}\text { Plat- } \\
\text { ing } \\
\text { effic- } \\
\text { iency } \\
(8)\end{array}$ & $\begin{array}{l}\text { Doubling } \\
\text { time (h) }\end{array}$ \\
\hline $\mathrm{H} 3 / \mathrm{P} 3$ & $3.5 \times 10^{5}$ & $3.5 \times 10^{6}$ & 3 & 10 & 1 & 22 \\
\hline H3 / P3 & $3.5 \times 10^{5}$ & $4.0 \times 10^{6}$ & 6 & 11 & 5 & - \\
\hline H3 / P4 8 & $5.0 \times 10^{4}$ & $1.8 \times 10^{6}$ & 3 & 36 & 25 & 14 \\
\hline $\mathrm{H} 3 / \mathrm{P} 48$ & $5.0 \times 10^{4}$ & $3.5 \times 10^{6}$ & 6 & 70 & 6 & - \\
\hline H3 / P64 & $2.0 \times 10^{5}$ & $9.0 \times 10^{6}$ & 3 & 45 & 28 & 13 \\
\hline $\mathrm{H} 3 / \mathrm{P} 64$ & $2.0 \times 10^{5}$ & $7.0 \times 10^{6}$ & 6 & 35 & 49 & - \\
\hline $\mathrm{H} 3 / \mathrm{PI}$ & $3.5 \times 10^{5}$ & $3.5 \times 10^{6}$ & 4 & 10 & 1 & 28 \\
\hline $\mathrm{H} 3 / \mathrm{P} 1$ & $3.5 \times 10^{5}$ & $5.0 \times 10^{6}$ & 4 & 14 & - & 25 \\
\hline $\mathrm{H} 3 / \mathrm{P} 45$ & $5.0 \times 10^{4}$ & $2.7 \times 10^{6}$ & 4 & 54 & 9 & 17 \\
\hline $\mathrm{H} 3 \mathrm{CE} / \mathrm{P} 4 \mathrm{O}$ & $5.0 \times 10^{4}$ & $1.7 \times 10^{6}$ & 4 & 34 & 13 & 19 \\
\hline $\mathrm{H} 3 \mathrm{CE} / \mathrm{P} 45$ & $5.0 \times 10^{4}$ & $1.0 \times 10^{6}$ & 3 & 20 & 30 & 17 \\
\hline $\mathrm{H} 3 \mathrm{CE} / \mathrm{P} 45$ & $5.0 \times 10^{4}$ & $1.6 \times 10^{6}$ & 6 & 32 & 6 & - \\
\hline
\end{tabular}

${ }^{a} A 11$ cells grown in medium DH-10 $\Delta$. 


\begin{tabular}{llcc} 
Table 2. & $\begin{array}{l}\text { Survival assay of SHE cells exposed to } \\
\text { rays }\end{array}{ }^{60} \mathrm{Co} \gamma$ \\
\hline $\begin{array}{l}\text { Cell line/ } \\
\text { passage no. }\end{array}$ & $\begin{array}{l}\text { Growth period } \\
\text { (days)/Cell cycle }\end{array}$ & $\begin{array}{c}\text { Plating } \\
\text { efficiency } \\
(8))^{b}\end{array}$ & $\begin{array}{l}\text { Survival } \\
\text { rate }(8)\end{array}$ \\
\hline $\mathrm{H} 3 / \mathrm{P} 1$ & $\begin{array}{l}4 / \log \text { cells } \\
\text { (Asynchronous) }\end{array}$ & 1 & 91 \\
$\mathrm{H} 3 / \mathrm{P} 45$ & $\begin{array}{l}\text { 4/log cells } \\
\text { (Asynchronous) }\end{array}$ & 9 & 97 \\
$\mathrm{H} 3 / \mathrm{CEP} 40$ & $\begin{array}{l}\text { 4/log cells } \\
\text { (Asynchronous) }\end{array}$ & 13 & 69 \\
\hline
\end{tabular}

${ }^{\mathrm{a} D o s e}$ rate $=14 \mathrm{cGY} / \mathrm{min}$, dose $=96 \mathrm{cGY}$.

'In medium DH-10 $\Delta$. 
Table 3. Survival assay of SHE cells exposed to UV radiation ${ }^{\mathrm{B}}$

\begin{tabular}{llcc}
\hline $\begin{array}{l}\text { Cell Line/ } \\
\text { passage no. }\end{array}$ & $\begin{array}{l}\text { Growth period } \\
\text { (days)/Cell cycle }\end{array}$ & $\begin{array}{c}\text { Plating } \\
\text { efficiency } \\
(8)\end{array}$ & $D_{0}$ \\
\hline H3/P3 & $\begin{array}{l}\text { 3/log cells } \\
\text { (Asynchronous) } \\
\text { 6/confluent cells } \\
\text { (Synchronous) }\end{array}$ & 1 & 6.5 \\
H3/P3 & 3/log cells & 1 & 4.5 \\
H3/P48 & $6 /$ confluent cells & 65 & 1.0 \\
H3/P48 & 3/log cells & 28 & 1.0 \\
H3/P64 & $6 /$ confluent cells & 49 & 6.0 \\
H3/P64 & 3/log cells & 30 & 1.0 \\
H3CE/P43 & $6 /$ confluent cells & 6 & 2.0 \\
H3CE/P43 & & 6 & 6 \\
\hline
\end{tabular}

${ }^{\text {a Dose rate }}=2.5 \mathrm{~J} \cdot \mathrm{m}^{-2} \cdot \mathrm{sec}^{-1}$.

'In medium $\mathrm{DH}-10 \Delta$. 
Table 4. Summary of parameters affected by cell passage number

\begin{tabular}{|c|c|c|c|c|}
\hline Passage no. & $\begin{array}{c}\text { Doubling time } \\
\text { (h) }\end{array}$ & $\begin{array}{c}\text { Plating } \\
\text { efficiency } \\
(\%)\end{array}$ & $\begin{array}{l}\text { UV sensitivity } \\
\text { (cell cycle) }\end{array}$ & $\begin{array}{l}\text { No. of } \\
\text { cells/plate }\end{array}$ \\
\hline 3 & 22 & .5 & confluent $>\log ^{a}$ & $1.5 \times 10^{7}$ \\
\hline 43 & 17 & 6 & $\log >$ confluent & $4.0 \times 10^{6}$ \\
\hline 48 & 14 & 6 & $\log t$ confluent & $4.0 \times 10^{6}$ \\
\hline 64 & 13 & 49 & $\log \equiv$ confluent & $6.0 \times 10^{6}$ \\
\hline
\end{tabular}

${ }^{a} \log$ phase $=$ exponentially growing cells 


\section{FIGURE LEGENDS}

Figure 1. Plot of plating efficiency $(x)$, growth doubling time (.), and the number of confiuent cells per $100-\mathrm{mm}$ plate $(\Delta)$ as a function of cell culture passage number. Cell growth doubling times and plating efficiencies (\% control) use the left $y$-axis, while the numbers of confluent cells per plate use the right $y$-axis. Arrows indicate the passages at which concentrations of fetal calf serum (FCS) were changed from $20 \%$ to $10 \%$ in the culture medium.

Figure 2. Plot of the cell number per plate as a function of the growth period per day. The doubling time $\left(T^{2}\right)$ is indicated for each of four different cell passages. H3 cells are SHE cell fibroblasts at various different passages (passage $64=x ;$ passage $3=$; passage $48=\Delta$ ). H3CE cells (at passage 43) show features of epidermal cells. The percentages indicate the plating efficiencies of the cells at the indicated points.

Figure 3. Survival curves as a function of UV dose with a dose rate of $2.5 \mathrm{~J} \cdot \mathrm{m}^{-2} \cdot{ }^{-1}$ for $\mathrm{SHE}-\mathrm{H} 3$ cells at $\mathrm{A}$, passage $3 ; \mathrm{B}$, passage 48; and $C$, passage 64. D, curves for the epidermal-1ike cell line in passage 43. Cells were irradiated in $\log$ phase ( $\Delta$ ) or when confluent (.). 
Figure 4. SHE cells from various passages ( 1 1-p45) were grown to confluence. Fibroblast (H3) and epidermal (H3CE) cells were used. Untreated $(0)$ and $\gamma$-ray $(\gamma)$ exposed (96 cGy) cells were harvested $1 \mathrm{~h}$ following completion of the exposure. RNA was purified and analyzed by Northern blot hybridization to (A) $\gamma$-actin, (B) PCNA, and (C) p53 probes. Fig. $4 \mathrm{~A}$ is a phosphorimager print; all others are $x$-ray films. Total RNA loaded was $20 \mu g ;$ poly A+ RNA loaded was $5 \mu \mathrm{g}$ in each well.

Figure 5. Differential display pattern for cDNA from unexposed (0), $\gamma$-ray-exposed $(\gamma)$, or UV-exposed (UV) cells. RNA was harvested $1 \mathrm{~h}$ after completion of the exposure. Gammaray exposures were $96 \mathrm{cGy}$ at a dose rate of $14 \mathrm{cGy} / \mathrm{min}$. UV exposures were $30 \mathrm{Jm}^{2}$ at a dose rate of $2.5 \mathrm{Jm}^{-2} / \mathrm{sec}$. Numbers in parentheses are the number of hours after exposure that the cells were harvested. The passages 3 and 40 are designated. Brackets demarcate the labeled primer used in each set. For $\mathrm{T}_{11} \mathrm{CA}^{*}-\mathrm{R}_{1}$, the first primer is labeled. For $\mathrm{T}_{11} \mathrm{CA}-\mathrm{R}_{1}, \mathrm{R}_{1}$ is labeled. Lanes marked with $A^{+}$used poly $(A)^{+}$-derived RNA. All others used total RNA. 
Cell Growth Doubling Time/Plating Efficiency (\% Control)

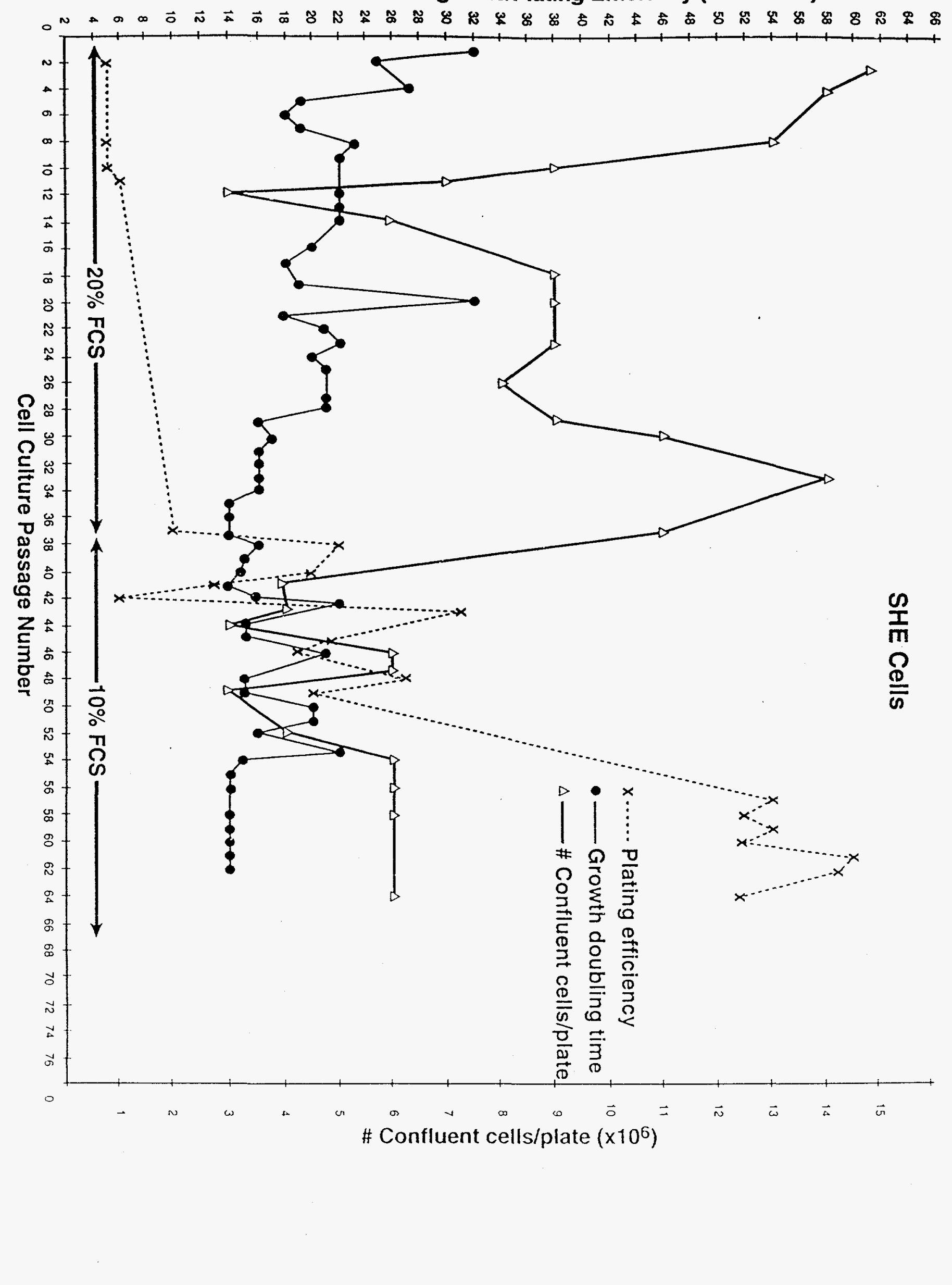




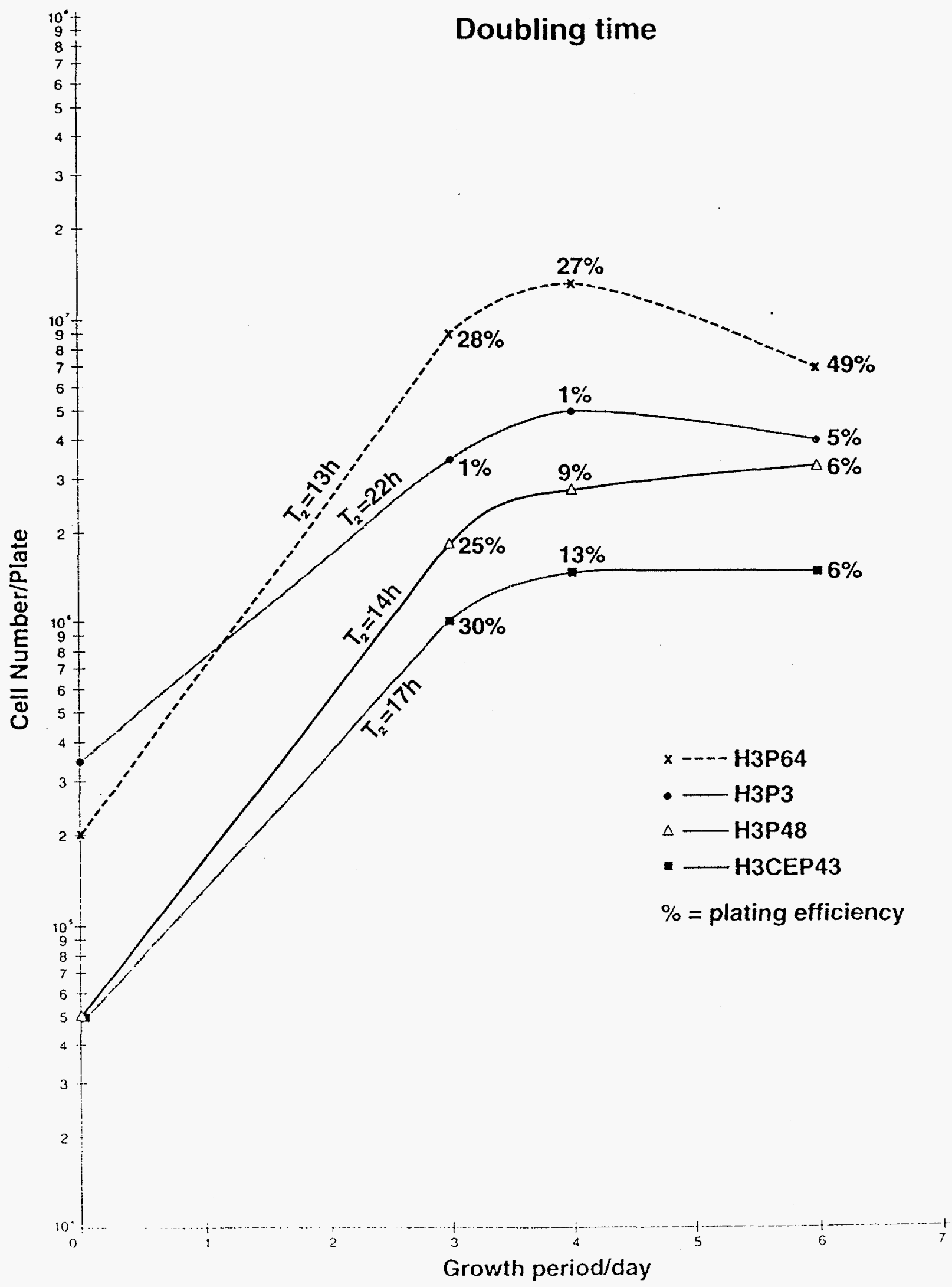

Chang-Liu and Woloschak Figure 2 


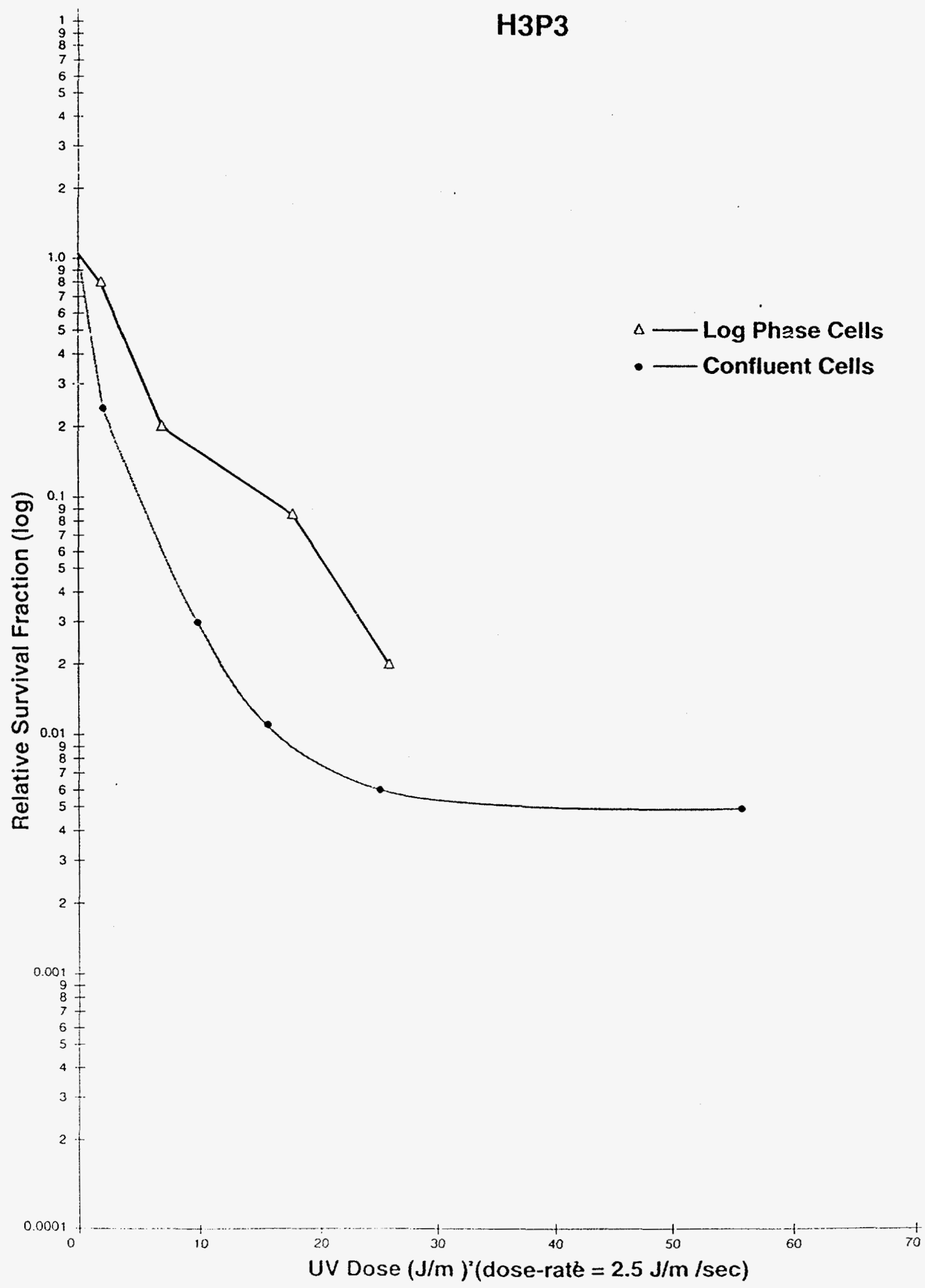

Chang-Liu and Woloschak Figure $3 \mathrm{~A}$ 


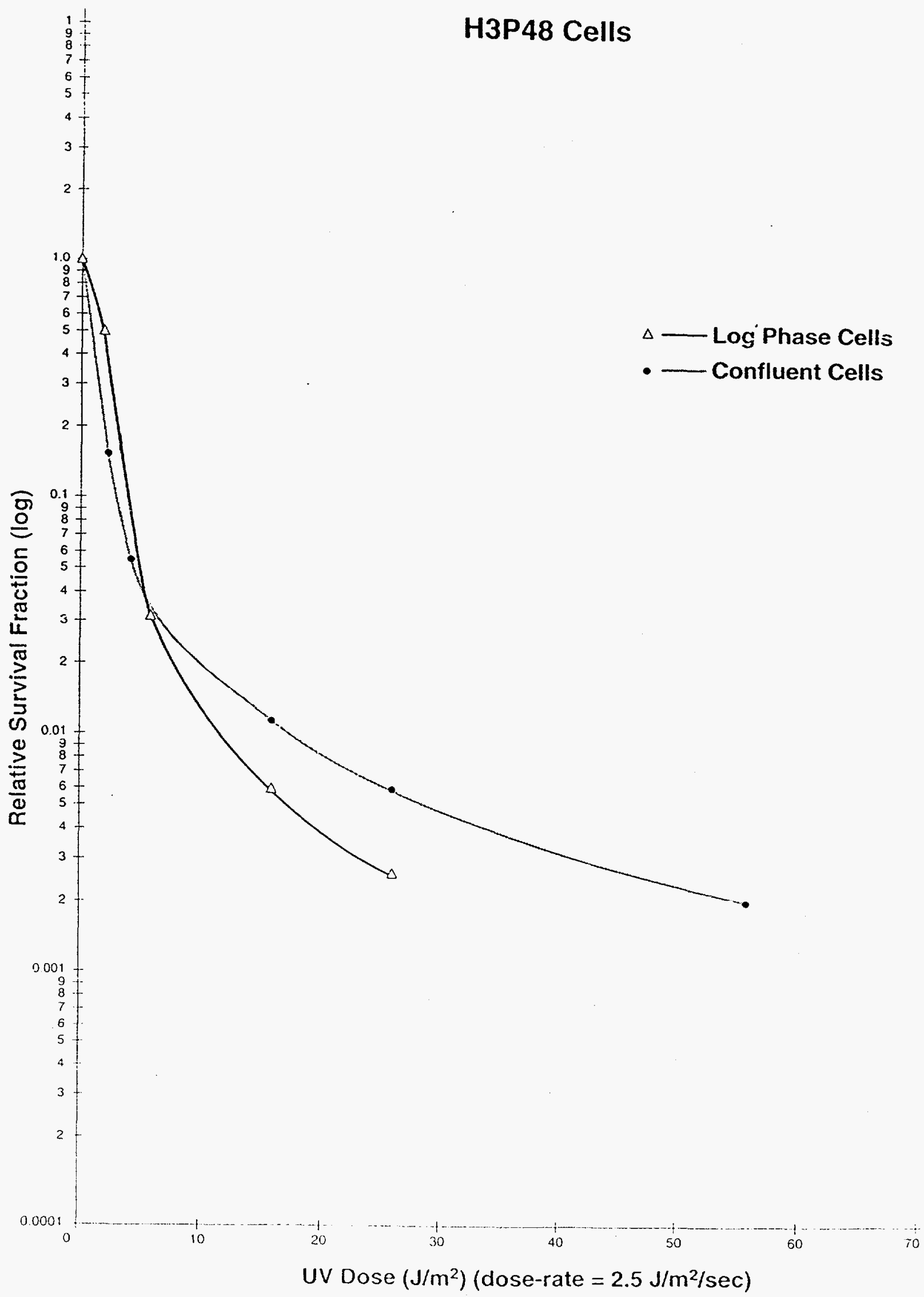

Chang-Liu and Woloscha: 


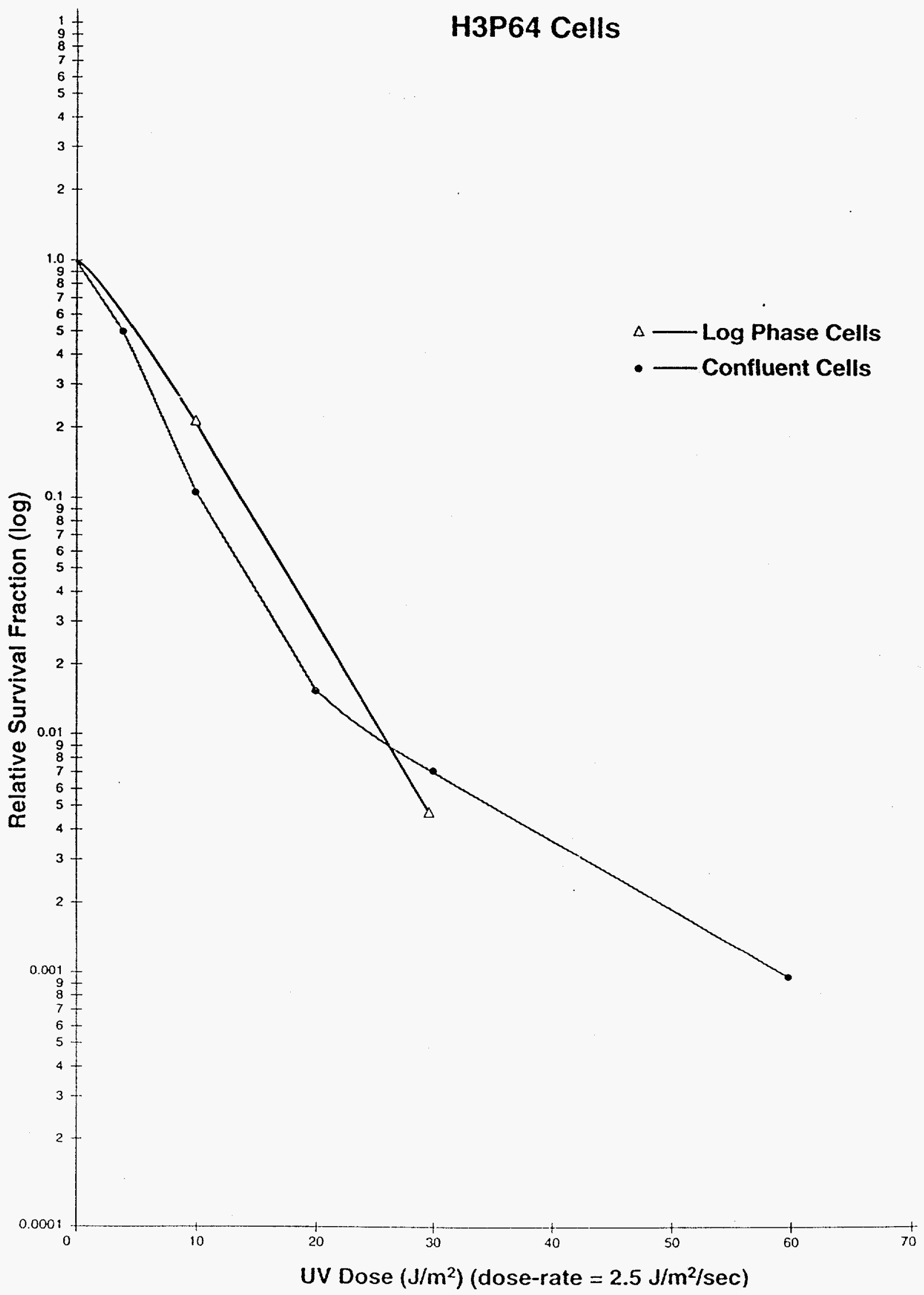

Chang-Liu and Woloscha

Figure $3 \mathrm{C}$ 


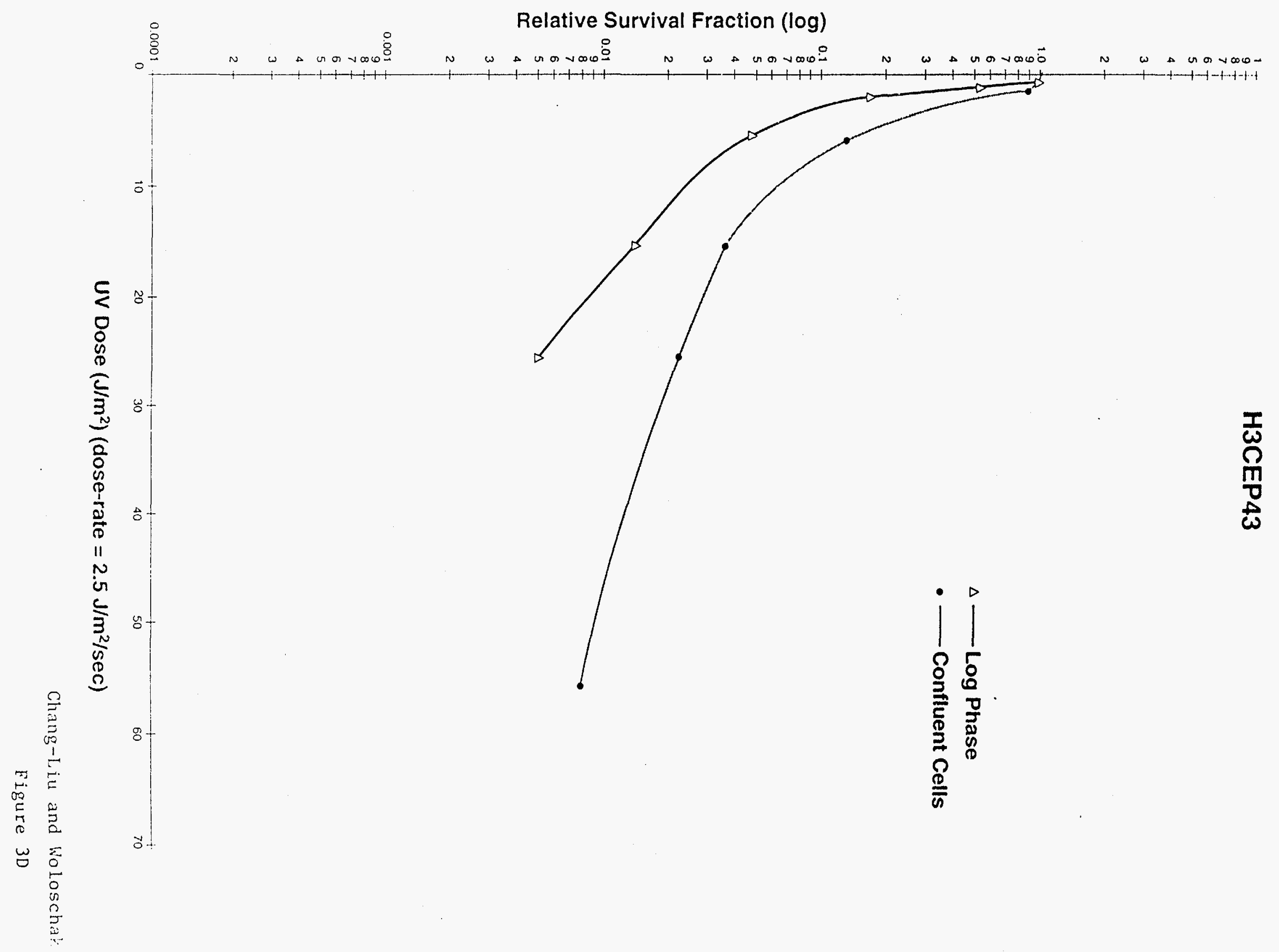




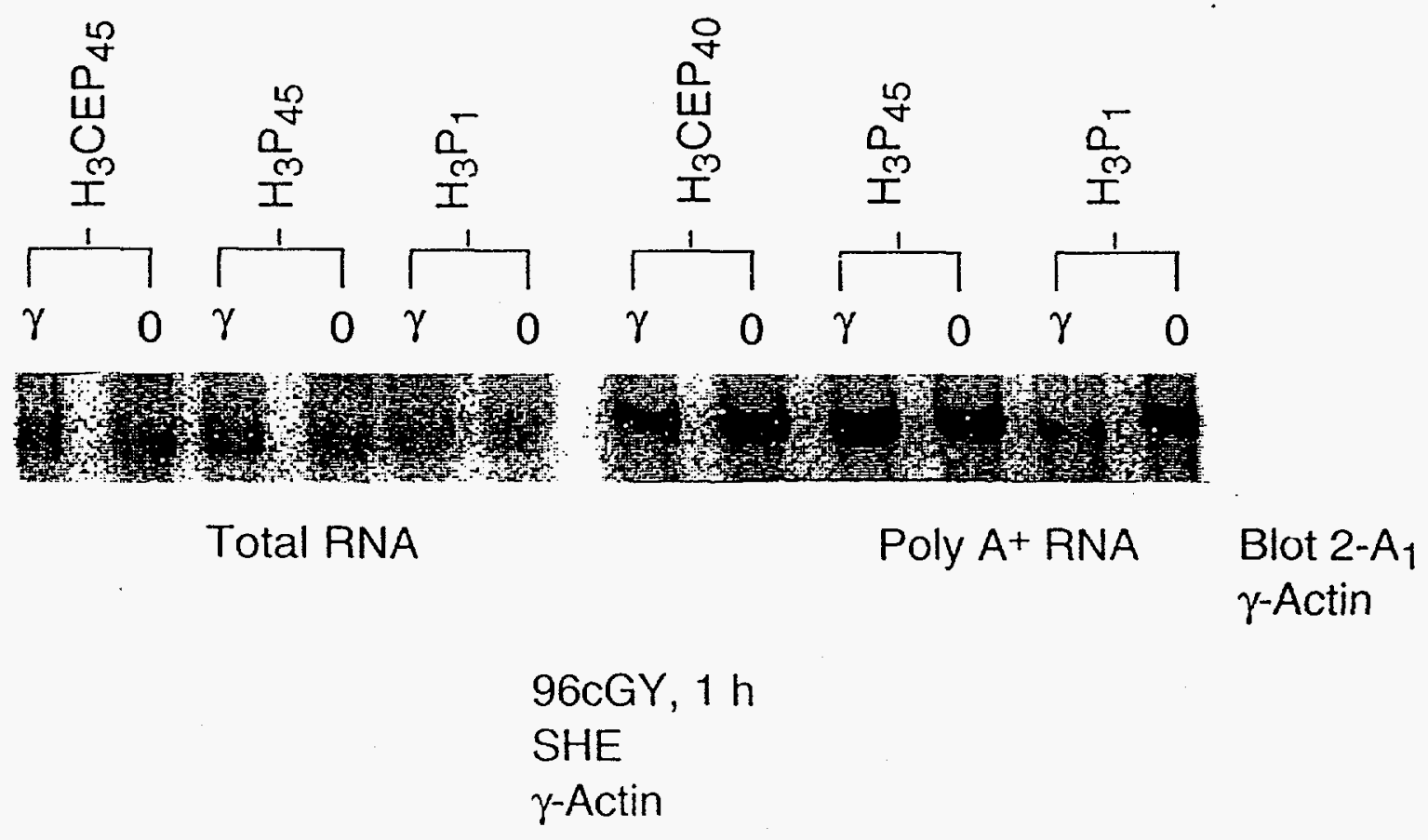

Chang-Liu and Woloschat

Figure $4 \mathrm{~A}$ 


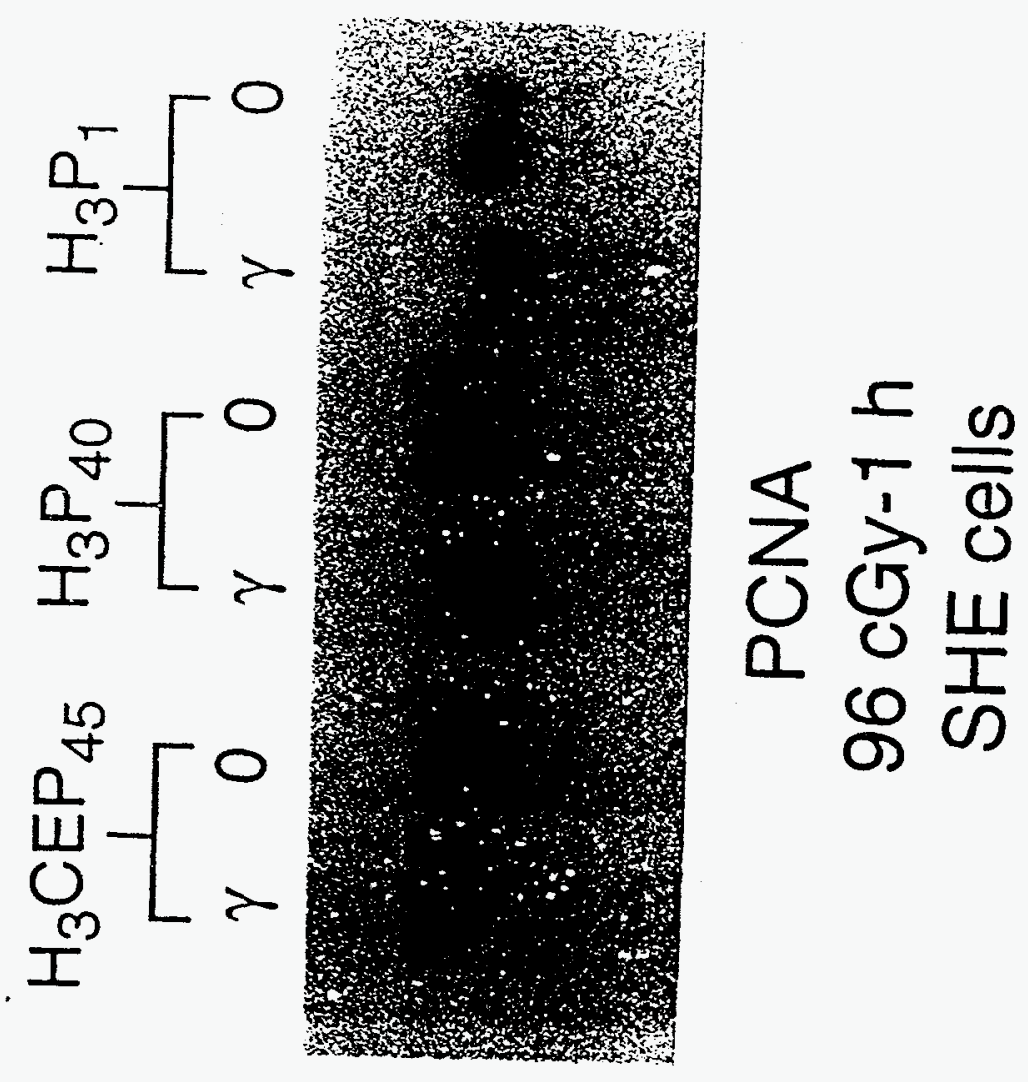




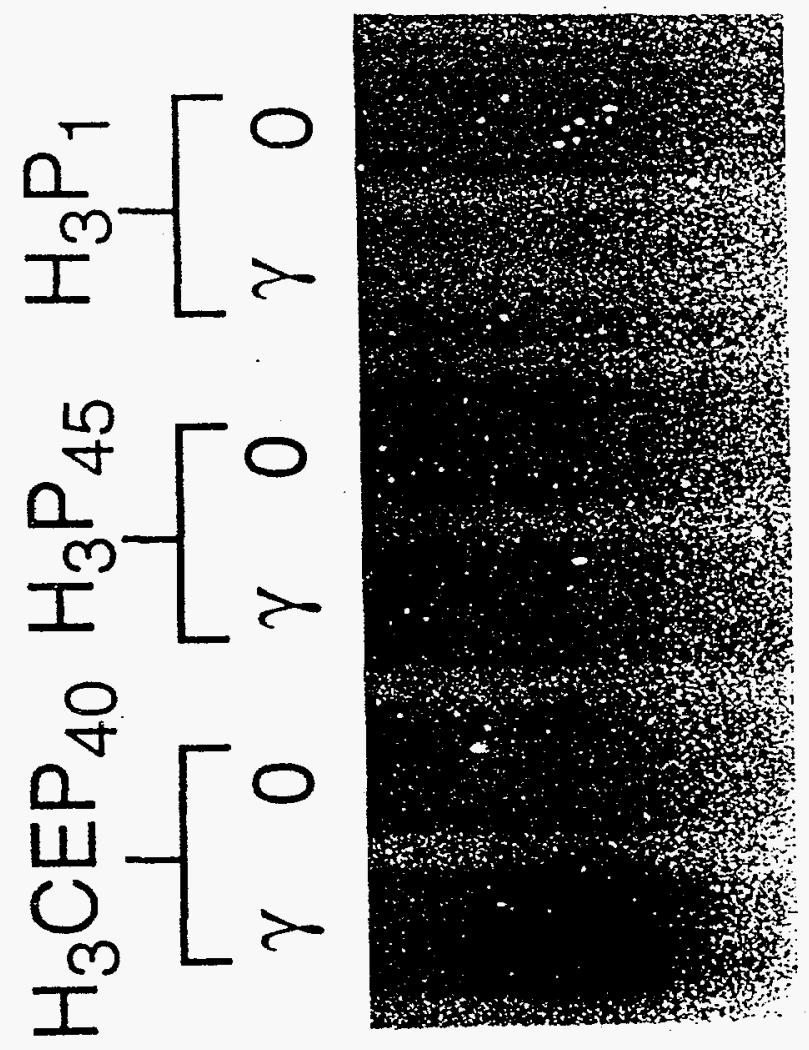

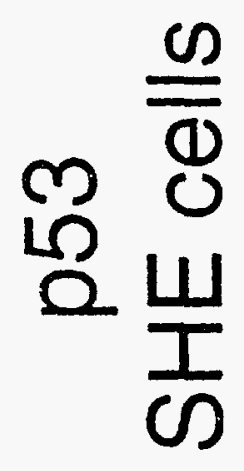




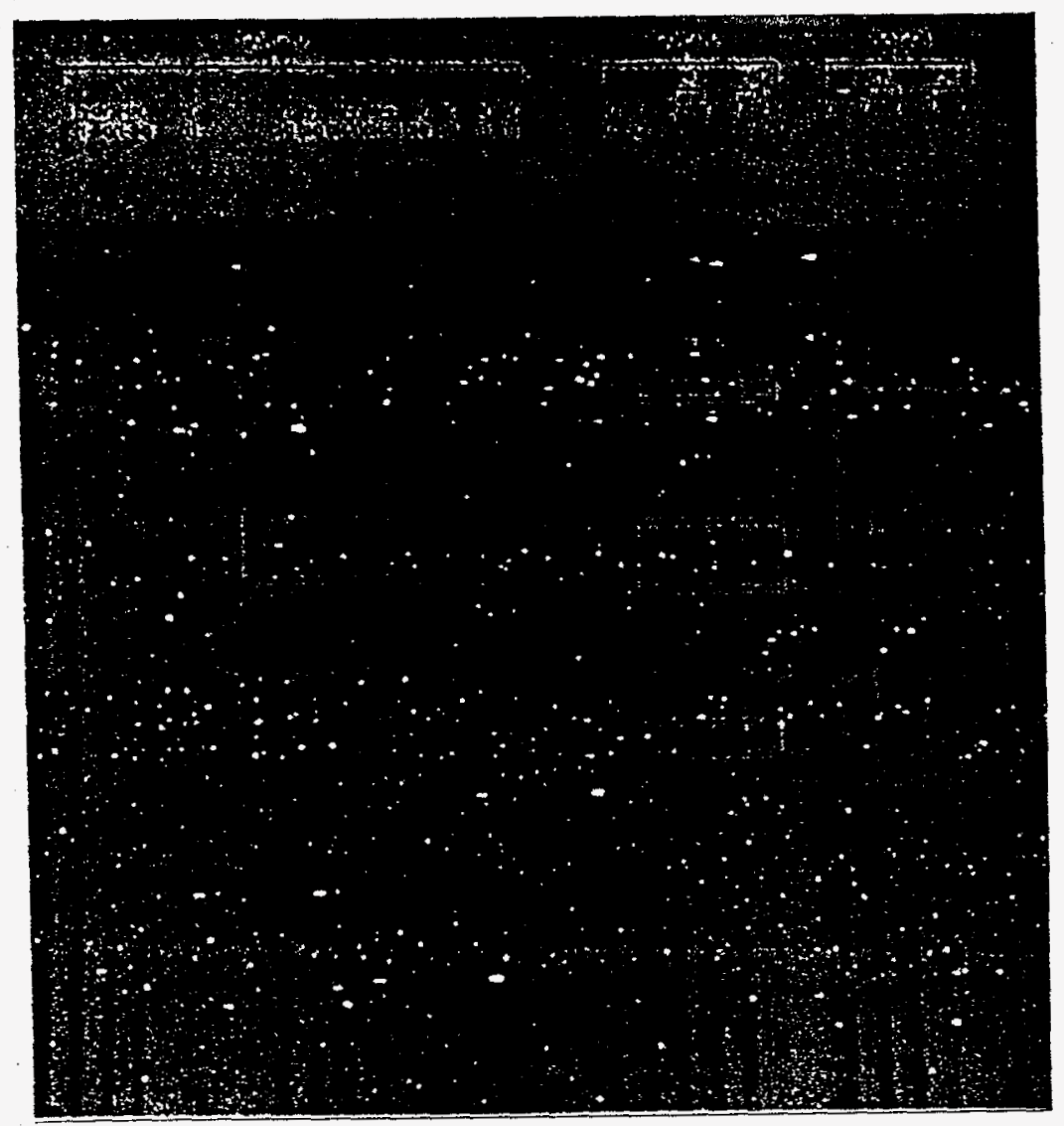

$\gamma-96 \circ G y$ ( $14 \circ G y / m i n)$ UV $30 \mathrm{~s} / \mathrm{m}_{2}\left(2.5 \mathrm{~J} / \mathrm{m}_{2} \mathrm{~g}^{\prime} \mathrm{sec}\right)$ 